\title{
ECONOMICS
}

\section{The problem of implementing social responsibility in Ukraine agro-industrial enterprises}

\author{
V. Nahorniy, O. Chetveryk
}

National University of Life and Environmental Sciences of Ukraine, Kyiv, Ukraine

Corresponding author. E-mail: nagornyvitaliy@gmail.com; chetveryk_OV@ukr.net

Paper received 20.09.17; Revised 27.09.17; Accepted for publication 30.09.17.

https://doi.org/10.31174/SEND-HS2017-146V24-01

\begin{abstract}
The main methodological approaches to the formation of corporate social responsibility are reviewed in the article. A brief analysis of the understanding of modern business in this category is conducted. The introduction of CSR into business practices to enhance competitiveness is considered as an example of an agro-industrial enterprise. As a result, the algorithm for the gradual application of social responsibility and the possible results are presented.
\end{abstract}

Keywords: social responsibility, competitiveness, CSR, profit, reputation, social position, social report.

Introduction. During the formation of economically sustainable production potential of an enterprise, an important role is played by its reputation, recognition by society, and also the quality of products that are the levers that bring profit to the entity and provide opportunities for strengthening competitive positions in the domestic and foreign agrarian markets.

In accordance with such positions the business activity requires the orientation of the transition to the social business, which is defined in the list of the main competitive advantages in the system of competitive relations of subjects of agrarian business.

The implementation of social responsibility is one of the components of the company's business aimed at increasing the value of business assets through the strengthening of reputation, company image, brand, product quality, increased customer and employee loyalty, environmental protection, transparency and public accountability in business practices, etc..

Object of research: processes of social responsibility activation of agribusiness' subjects.

Subject of research: theoretical and applied aspects of the formation and functioning of social responsibility in view of improving the competitiveness of agrarian enterprises.

A brief overview of publications on the topic. Questions in the whole of the subject under study are reflected in the writings of such scholars as: A.M. Kolota [12]. G.F. Horuzhyi [8]. V.M. Shapoval [13]. O. IU. Ermakov [6]. O.P. Gogul, I.P. Kudrinova [2]. O.F. Novikova, M.IE. Deich, O.V. Pankova [3]. I. M. Tsaryk [14].T. R. Antoshko, P.V. Krush, IU. V. Tulenova [1] and others. However, in spite of a significant number of scientific publications, there is no common consensus in contemporary economic literature on understanding the content of the concept of social responsibility of agri-food enterprises.

Aim The purpose of the article is to determine the processes of activating the social responsibility of agribusiness subjects and their current realities.

Materials and methods In the course of the study, general scientific and special economic methods were used, namely: the dialectical method, the methods of analysis and synthesis, the method of historical-logical analysis and the method of system analysis.
The main material presenting: The essence of social responsibility of agrarian business' subjects, which is an extremely complex and multidimensional phenomenon, has different interpretations in modern economic science. The social responsibility of agribusiness enterprises is defined as the current activity of the company, aimed to the increasing of the value of business assets through the strengthening of reputation, company image, brand, customer loyalty and employees, transparency and public reporting in business practice. The modern European model of social responsibility of business is based on three areas of initiative - the economy, employment and the environment. We suppose that each of the definitions is true, and especially in its complex (Figure 1).

On the basis of the research, it was established that entrepreneurial structures of various scales, forms of property and activities are subjects of agroindustrial business, which bear the social responsibility to a wide range of objects, namely owners, hired workers, consumers, partners, local community, national economy, international community. Most of the polled Ukrainian companies (78.1\%) know about social responsibility of business. Although the above level is relatively high, it is not right to conclude that this concept is widely known to all actors, since every fifth enterprise in Ukraine is not aware of such a widely-spread practice in the world. The results of a survey of 1221 top managers of Ukrainian companies, conducted in October 2005 in the six most industrialized cities and regions of Ukraine (namely, Kyiv, Kharkiv, Lviv, Dnipropetrovsk, Donetsk and Odesa) by means of a personal interview. The majority of companies attribute social responsibility to the implementation of social programs for improving the working conditions of staff $(65.5 \%)$, staff development and training $(63.2 \%)$, charitable assistance to the public $(56 \%)$, ethical attitude towards buyers $(49.5 \%)$

According to a recently published study of the results of the World Economic Forum, under the Global Competitiveness Index 2015-2016 Ukraine ranked the 79th among 140 countries, having lost three positions in the year (ranking the 76th in the previous ranking) [5].

The modern Ukrainian economy and entrepreneurship are considering a variant of CSR as a mix of British and European models. The characteristic feature of which is state regulation. However, the activity of the corporations 
themselves in implementing their own social projects is increasingly becoming apparent.

Only a fifth of companies have an appropriate budget for social responsibility and are preparing social (nonfinancial) annual reports. The most active representatives in this field are foreign companies and the largest Ukrainian enterprises. Today, we can distinguish three levels of social responsibility of Ukrainian business [11]. Compliance with legal obligations to the state and society (taxes, environmental norms, labor protection), as stated by the majority of enterprises of Ukraine, registered and acting on legal bases.

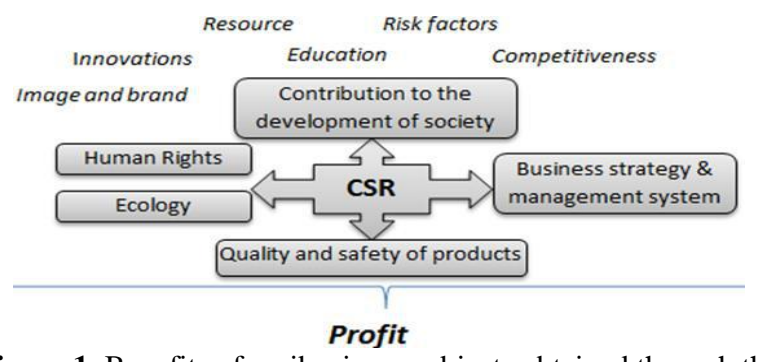

Figure 1. Benefits of agribusiness subjects obtained through the introduction of social responsibility

The reasons of the emergence of social responsibility in the developed countries are not primarily related to philanthropy and social protection, but primarily to improving investment attractiveness and image, and to increase the reputation of organizations. However, the vector for the introduction and development of CSR is aimed to the increasing of social status and creating a positive reputation. The idea of introducing social responsibility itself is related to the need to ensure sustainable development, to achieve a balance of interests between the state, business and society. The simplest form of social responsibility is the timely payment of labor, taxes and the creation of new jobs. A more perfect form involves the improvement of the skills of employees, the construction of social housing, the full development of the social sphere [10].

The size of an enterprise is the best indicator for implementation of social report of company's events: the larger the company, the greater the likelihood that the company will be engaged in compiling a social report. Almost all enterprises $(99.0 \%)$ out of more than 500 workers carry out social responsibility measures, compared with $77.2 \%$ of enterprises with fewer than 50 employees. On the contrary, only $1 \%$ of enterprises with more than 500 employees do not implement social reporting measures compared with the fourth part of small enterprises $(22.8 \%)$. (figure 2 )

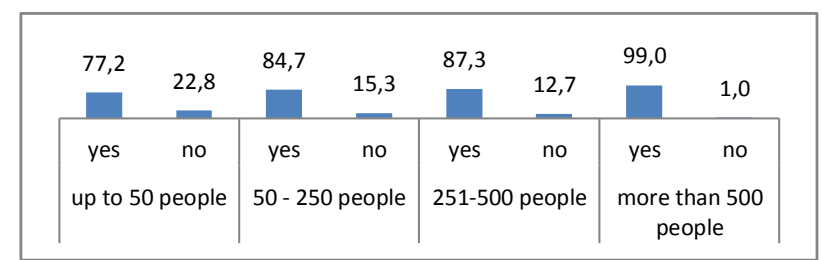

Figure 2. The implementation of the social reporting by the size of an enterprise

As Figure 3 shows, $84.7 \%$ of companies never hold their wages, $65.5 \%$ of firms regularly raise wages and pay bonuses, $64.3 \%$ of enterprises do not pay attention to employment and career growth by gender, age, religion and political beliefs, $63.9 \%$ of companies carry out and support job-careers training.

The most common explanation of the essence of corporate social responsibility (CSR) as «promoting the practice of responsible business that benefits business and society and contributes to social, economic and environmentally sustainable development by maximizing the positive impact of business on society and minimizing negative» [7 p. 23]. CSR at many points is the bridge between the micro and macro level of making ethical decisions in business [4, p.160].

Let's consider the understanding of corporate social responsibility and the practical implementation of its elements by the modern business of Ukraine on the example of the Pavlovsky Beer Plant located in Volyn region and has its unique history, the main production activity of which is production of live beer, malt, mineral and sweet water.

Employees of the company are the main element in which most companies direct social responsibility measures. So the season at the investigated enterprise in the season more than 130-150 employees of them are 24 employees.

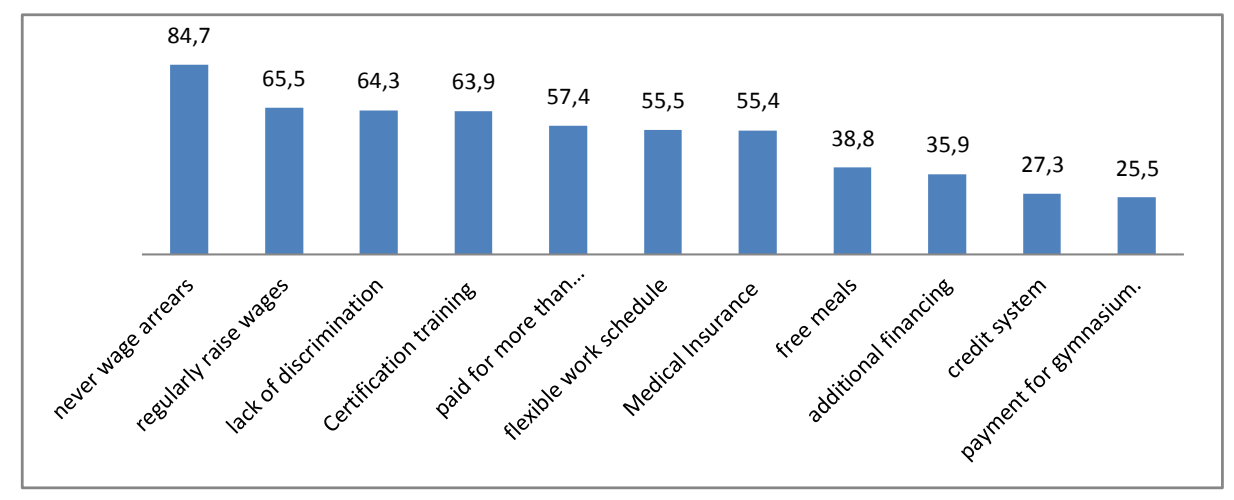

Figure 3. Social responsibility of enterprises before their employees

Wages among workers vary in the amount of 4.5-6 thousand hryvnias, among employees - 5.5-8.5 thousand. The personnel policy of the company is aimed to the ensuring the proper level of qualification of its employees with modern technological needs. The program of measures to plan and strengthen the personnel policy of the enterprise involves conducting attestations of the managers and specialists of the plant, carrying out the 
training of personnel with methods of training and familiarization with advanced methods of work. The slogan of the company sounds like «People are our tremendous value». The accounting system adopted by the company meets the requirements of the current legislation of Ukraine, the financial statements are made up of valid accounting data and, in all material aspects, fairly, relia- bly and fully disclose the required financial information about the Company. In general, we can say that the enterprise gradually builds up its material and technical base, modernizes equipment for providing high-quality products and reduces costs in production of products, as well as reducing the negative impact on the environment and health of workers.

The dynamics of sales of products (beer) of LLC «Pavlovsky Beer Plant» for 2013-2015

\begin{tabular}{|c|c|c|c|c|c|c|c|c|}
\hline \multirow{2}{*}{} & \multicolumn{2}{|c|}{$\mathbf{2 0 1 3}$} & \multicolumn{2}{c|}{$\mathbf{2 0 1 4}$} & \multicolumn{2}{c|}{2015} & \multicolumn{2}{c|}{ \%2015 to 2013 } \\
\cline { 2 - 8 } & $\begin{array}{c}\text { Draft } \\
\text { beer }\end{array}$ & $\begin{array}{c}\text { Beer } \\
\text { Bottle }\end{array}$ & $\begin{array}{c}\text { Draft } \\
\text { beer }\end{array}$ & $\begin{array}{c}\text { Beer } \\
\text { Bottle }\end{array}$ & $\begin{array}{c}\text { Draft } \\
\text { beer }\end{array}$ & $\begin{array}{c}\text { Beer } \\
\text { Bottle }\end{array}$ & $\begin{array}{c}\text { Draft } \\
\text { beer }\end{array}$ & $\begin{array}{c}\text { Beer } \\
\text { Bottle }\end{array}$ \\
\hline $\begin{array}{c}\text { Total for } \\
\text { the year }\end{array}$ & 519152 & 812905 & 476459 & 683135 & 418528,5 & 564611 & 80,62 & 69,46 \\
\hline
\end{tabular}

After analyzing the dynamics of sales of products from the main activities of the enterprise, we can say that in 2015 , the sale of beer has decreased by $20 \%$ for the implementation of draft beer and by $30 \%$ for the sale of beer in bottles. However, the company has not lost its profit, which can be regarded as having increased the cost of sales of products, as well as reasonable, responsible consumption of beer.

The company's successful activities are witnessed by a gradual increase of profits. The analysis of Table 3 allows us to conclude that in difficult times for doing business in Ukraine, with the growth of different types of costs and cost of production, the company is able to receive good profits, which testifies to the rapid development of the company. The presence of own wells significantly reduces the dependence on external supply of water, reduces the cost of produced beer and mineral water, guarantees the continuity of production and the maximum yield of quality finished product.

\begin{tabular}{|l|c|c|c|c|}
\hline \multicolumn{1}{|c|}{ INDICATOR } & $\mathbf{2 0 1 3}$ & $\mathbf{2 0 1 4}$ & $\mathbf{2 0 1 5}$ & $\mathbf{2 0 1 5} / \mathbf{2 0 1 3} \%$ \\
\hline Net profit & 7810 & 6762 & 8478 & 108,5 \\
\hline cost of sold products & 5162 & 5582 & 6792 & 131,6 \\
\hline Gross profit & 2648 & 1180 & 1686 & 63,7 \\
\hline Other operating income & & 116 & 189 & \\
\hline Administrative expenses & 333 & 423 & 684 & 205,4 \\
\hline Selling expenses & 132 & 145 & 102 & 77,3 \\
\hline Other operating expenses & 1160 & 133 & 170 & 14,7 \\
\hline Financial result of operating activities: profit & 1047 & 595 & 919 & 87,8 \\
\hline Net financial result: profit & 849 & 488 & 754 & 88,8 \\
\hline
\end{tabular}

Table 3. Financial results of LLC «Pavlovsky Beer Plant»

Realizing their influence on the environment in which the company operates and taking full responsibility for society, employees and shareholders, plant managers implement and use socially responsible approaches and technologies in their day-to-day work. Yes, LLC «Pavlovsky Beer Plant»: regularly provides information on corporate social responsibility in the form of a Social Report. implements a number of energy-efficient and environmentally-friendly programs so in 2015 , the company managed to reach the start of waste-free production.

The main areas of eco-responsibility of the company are the gradual reduction of atmospheric emissions, rational use of water resources and the recycling of industrial waste. in 2015 , by $15 \%$ reduced greenhouse gas emissions into the atmosphere due to the system of boilerhouse boiler equipment. Today, brewing companies are equipped with special facilities for the processing of $\mathrm{CO}_{2}$. so the carbon dioxide emissions in the air each year decrease by $10-15 \%$. Within the framework of the policy of reducing the production impact on the environment over the past year, 10 tons reduced emissions of grain dust, carbon monoxide and nitrogen compounds into the air.

In 2015, the company saved nearly 100 million liters of water due to its reuse in technological processes. Production structures are equipped with a system of modern gravity and sorption purification facilities, which remove pollution of sewage with a hydraulic gravity up to $0.2 \mathrm{~mm}$ / s. Today, the company sells, recycles and reuses $96 \%$ of its own waste products, including beer pellets, yeast and grain residues, and plastics.

Thus, we can conclude that the investigated company gradually implements the concept of social responsibility in production, which allows to enhance the image of the company and consumer confidence. Employees are proud of their work and try to work most effectively.

Having conducted research on the availability of corporate social responsibility at the enterprise, we can say that there is no clear plan for developing and implementing a deeper level of CSR. In order to increase the competitiveness of LLC «Pavlovsky Beer Plant», it is necessary to clearly identify the mission of the company and its strategic path for the future. So you can apply such an algorithm for introducing social responsibility at the enterprise (figure 4)

Improving business reputation at the expense of social responsibility will increase the investment attractiveness, as well as potentially provides the basis for the more effective development of new markets and business areas. For example, foreign investors, when choosing where to invest, first of all pay attention to whether the company uses corporate social responsibility and, if so, at what level. 
The company's social responsibility can be seen as an additional opportunity to expand the dialogue with all stakeholders and help build mutually beneficial partnerships. Information openness is a basic principle when dealing with interested parties.

However, it is a pity, at the current stage, social responsibility is predominantly one-time for Ukrainian business organizations, aimed to the creating or improv-

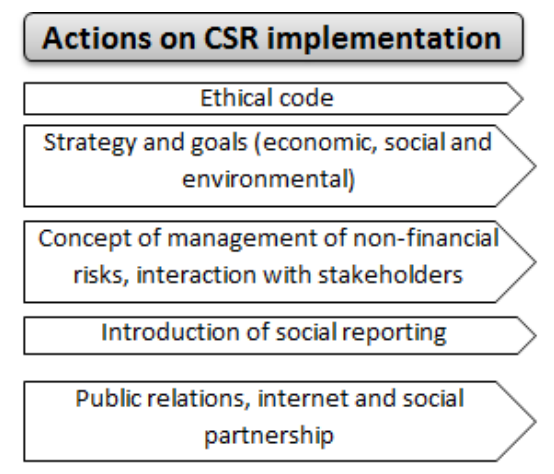

Figure 4. Algorithm and goals of socially responsible activity of the enterprise

Despite the positive experience of foreign business in the developed world, in Ukraine there is still no economic justification for the existence of a close relationship between the social activities of the business and the improvement of financial results. Solving social problems may face the problem of lack of experience, which requires additional investment, for training their personnel or for attracting specialists from the side, studying the social problem, and most importantly, requires close cooperation with state and public institutions.

Although there is a system of social responsibility in Ukraine for a certain period, it is still informal in nature, due to the lack of a complete legal and regulatory framework that is not in accordance with international practice or real demands of socio-economic policy. Yes, it is worth using international standards of social responsibility, but one must not forget that the competitiveness of the Ukrainian economy is rather low, therefore, too strict requirements for entrepreneurship should be avoided.

Conclusions: So, we can conclude that corporate social responsibility in Ukraine is at the stage of its formation and formation. A high level of corporate social responsibility can positively affect the competitiveness of enterprises. However, without active support from the state, it is difficult to do so.

For business in modern realities, it is important not only the "growth» of the enterprise, but also the achievement of it with all the maximum responsibility. It is necessary to think about how decisions and actions will affect ing reputation and image, and there is still no clear, constructive dialogue and mutually beneficial interaction between employers and employees. Before the development of social responsibility, the state faces artificial and natural obstacles. In the national economy of Ukraine all levels of implementation of the concept of social responsibility are represented.

\section{Possible results \\ Improve image and business reputation \\ Investment attractiveness \& access to socially investments \\ Increase of capitalization \\ Improvement of relations with the authorities \\ Increase profits, increase company growth \\ Reduction of operating expenses \\ Customer lovalty, sales increase \\ Increase in labor productivity}

society, the environment, and most importantly the future of the enterprise.

As for the investigated enterprise, we see the creation of LLC «Pavlovsky Beer Plant» as the subject of socially responsible business in the following aspects. First of all, it is a fair business practice which, as a company policy, should be replicated with its internal and external interaction. Secondly, it is environmental protection and resource conservation. Almost any production in one way or another has an impact on the environment, so the corporate social business must implement comprehensive initiatives to reduce the harmful effects on the environment. Third, and one of the most important is the development of local society. Every entrepreneur must remember that the success of his business depends on the level of tension in the region where he works.

The policy of socially responsible companies should include social programs for the residents of the region of doing business, which includes support for socially vulnerable groups of the population, support for children and youth, support for the preservation and development of housing and communal services and objects of cultural and historical importance, and others. And, finally, the fourth is the development of personnel aimed at training and professional development, applying motivation schemes for wages, providing employees with a social package, creating conditions for recreation and leisure, maintaining internal communications in the organization, participation of employees in the adoption of management decisions.

\section{REFERENCES}

1. Antoshko T.R. Implementation of Corporate Social Responsibility at Industrial Enterprises: Monograph / T. R. Antoshko, P.V. Krush, IU.V. Tyulenieva; National tech Unitary of Ukraine "Kyiv. Polytechnic in-t ". - K.: NTUU "KPI", 2013 $275 \mathrm{p}$.

2. Gogula O.P. Social responsibility of business: monograph / O. P. Gogula, I.P. Kudinov; Cab Ministers of Ukraine, National university of life and environmental sciences of Ukraine. Nizhyn: Lysenko MM, 2011. - 175 p.

3. Diagnostics of the state and prospects of development of social responsibility in Ukraine (expert assessments): monograph / O.F. Novikova, M.IE. Deych, O.V.Pankova and others; National Academy of Sciences of Ukraine, Institute of Industrial Economics. - Donetsk, 2013. - 296 p.

4. Business Ethics [Text]: Teaching. Manual / V.V. Sokoliansky, V.A. Borodin. - M.: Moscow State University, 2006 (Moscow). - 191 pp., P.160.

5. Economic Discussion Club [E. source]. - Access mode : http://edclub.com.ua/analityka/pozyciya-ukrayiny-v- 
reytyngu-krayin-svitu-za-indeksom-globalnoyi-

konkurentospromozhnosti-0

6. Ermakov O.Yu. Social responsibility: A manual. - K .: CP "Komprint", 2015 - 191c.

7. Kotler F. Corporate Social Responsibility. How to do as much good as possible for your company and society / Kotler F., Lee N. / Per. from english - K .: Standard, 2005. - 302 pp., P. 23

8. Moral dimension of the economy: social responsibility of the business and economic efficiency: monograph / National Bank of Ukraine, University of Banking; Ed. G. F. Horuzhii. - K.: UBS NBU, 2009. - 255 p.

9. Petrushenko IU.N. Features of the implementation of the concept of social responsibility of business in the national economy of Ukraine / IU. N. Petrushenko // Journal of institutional studies. - 2013. - № 1, T. 5. - S. 92 - 107.

10. Methodological base of implementing CSR in Ukraine agricultural enterprises / O.Yu. Ermakov, V.V. Nahornyi // Scientific Bulletin of NUBiP of Ukraine - 2016. № 249. - P. 165 174.

11. Practice of charitable activities of business companies in Ukraine: current experience (report on research results) / A Gulevsk-Chernysh, D. Nepocchatov, L. Palivoda, S. Shenderovsky; per community Ed. A. Gulevskaya-Chernysh - K .: Salyutis, 2010. - $60 \mathrm{~s}$
12. Social Responsibility: Theory and Practice of Development: Monograph / A. M. Kolot et al. ; for sciences Ed. Dr. Econ. Sciences, prof. A.M. Kolot; State higher tutor shut up "Kiev national economic university by Vadim Hetman ", Sciences. Park, Institute of Social Work. relationships. - K.: KNEU, 2012. - $501 \mathrm{p}$.

13. Shapoval V.M. Social responsibility of business in the structure of management of economy: monograph / V.M. Shapoval; DVNZ "Nat. mountain un-t ". - D.: State. University "NGU", 2011. - 356 pp.

14. Tsarik I. M. Regulatory tools for strengthening social responsibility of business in the system of national economy: monograph / I. M. Tsaryk; Chernihiv state in-t of Law, soc. technologies and labor. - Chernihiv, 2011. - 152 p.

15. Friedman M. The Social Responsibility of Business is to Increase its Profits / M. Friedman // The New York Times Magazine. - 1970. - September 13 [E. source]. - Access mode: http://www.umich.edu/ thecore/doc/Friedman.pdf

16. Kitzmueller M. Economic Perspectives on Corporate Social Responsibility / M. Kitzmueller, J. Shimshack // Journal of Economic Literature. - 2012. - №. 50 (1). - P. 51 - 84.

17. Post J. E. Managing the extended enterprise: The new stakeholder view / J. E. Post, L. E. Preston, S. Sachs // California Management Review. 2002. - № 45 (1). P. 5 - 28.

\section{Проблема реализации социальной ответственности в Украинских агропромышленных предприятий В. В. Нагорный, Е. В. Четверик}

Аннотация. В статье рассмотрены основные методологические подходы к формированию корпоративной социальной ответственности. Проведен краткий анализ понимания современного бизнеса этой категории. Внедрение корпоративной социальной ответственности в деловую практику агробизнеса для повышения их конкурентоспособности рассматривается на примере агропромышленного предприятия. В результате представлен алгоритм постепенного применения социальной ответственности и возможные результаты.

Ключевые слова: сочиальная ответственность, конкурентоспособность, КСО, прибыль, репутация, соииальное положение, сочиальный отчет. 